\title{
Effects of aqueous extracts of two dominant weed species on seed germination and seedling growth of tobacco
}

\author{
B. A. Kumbhar and R. B. Shah \\ Botany department, Arts, Commerce and Science College, Borsad (Gujarat, India)
}

\begin{abstract}
The present study aimed at evaluating the effects of aqueous extracts of two dominant weed species on seed germination and seedling growth of tobacco. At the high concentration (6\%), leaf aqueous extract of digera muricata mart. Was found to have the inhibitoriest effect, whereas inflorescence extract of chinopodium murale l. was found very less inhibitory effect of nicotiana tabacum followed by those of the other plant extracts after five days. All aqueous extract of two weed species inhibited seed germination and seedling growth of nicotiana tabacum when compared with distilled water.
\end{abstract}

Keywords-aqueous, seed, germination, allelopathic, tobacco

\section{INTRODUCTION}

Allelopathy is defined as the direct or indirect, harmful or beneficial effects of one plant on another through the production of chemical compounds that escape into the environment (Rice, 1984). Chemicals that originate from plants or microorganisms impact many organisms in the ecosystem, but the term allelopathy has most often referred to the activity of these chemicals on other plants or microorganisms (Enhellig 2002). Plants produce a large variety of secondary metabolites like phenols, tannins, terpenoids, alkaloids, polyacetylenes, fatty acids and steroids, which have an allelopathic effect on the growth and development of the same plant or neighboring plants. Considerable knowledge has been obtained concerning the chemicals involved in allelopathy (Rice 1984; Narwal and Tauro 1994). Most research on allelopathy has focused on the effect of interaction among weed species (Narwal, S.S., 1994), weed and crop (Rice, E.L., 1984), and crop species (Chung, I.M. and D.A. Miller, 1995). Effects of aqueous extracts of two dominant weed species on seed germination and seedling growth of tobacco have been studied.

\section{MATERIAL AND METHODS}

Aqueous extracts of the inflorescence, leaf, stem and root were prepared by digesting $10 \mathrm{gm}$ of air dried Digera muricata Mart. and Chinopodium murale L. material in $100 \mathrm{ml}$ distilled water for $24 \mathrm{~h}$ at $25^{\circ} \mathrm{C} \pm 5^{\circ} \mathrm{C}$. It was filtered through whatmann filter paper no.1 of the volume of filtrate made to $100 \mathrm{ml}$ (Dhawan and Narwal 1994). Different dilution of the extract i.e. $2 \% .4 \%$ and $6 \%$ were prepared from this stock solution. Seeds of tobacco were soaked for $24 \mathrm{~h}$ in different concentrations of the extracts. For control seeds were soaked in distilled water only.

The seeds of tobacco were sterilized by dipping in the solution of $0.1 \% \mathrm{HgCl}_{2}$ for 1 min followed by $3-$ 4 washing under running tap water to remove residues of $\mathrm{HgCl}_{2}$ and dried in folds of ordinary filter papers in each Petri dish containing whatmann no. 1 filter paper was kept at the bottom and there after seeds arranged on the top of the filter paper. The Petri dishes were covered with glass covering. They were incubated for 5 days. The whole set of experiment was kept undisturbed at room temperature of $25^{\circ} \mathrm{C} \pm 5^{\circ} \mathrm{C}$.

\section{RESULTS AND DISCUSSION}

In seed germination, 25 seeds of tobacco were treated with $2 \% .4 \%$ and $6 \%$ concentration of two weed species (Digera muricata Mart. and Chinopodium murale L.) material and the result was observed after $2^{\text {nd }}$ and $4^{\text {th }}$ days as compared to control.

Seed germination: The seed germination of tobacco was influenced differently by various concentrations of two weed species (Digera muricata Mart. and Chinopodium murale L.) water extract. The highest concentration of Digera muricata Mart. water extract (6\%) weed species (and Chinopodium murale L.) significantly suppressed the seed germination after $2^{\text {nd }}(35 \%)$ and $4^{\text {th }}(32 \%)$ of Nicotiana tabacum. It indicates that germination decreased with an increase in the concentration of weed extract which suggested an high inhibitory effect of Digera muricata Mart. on tobacco seed germination. But, lower inhibitory effects of Chinopodium murale L.on seed germination of Nicotiana tabacum were observed after two and four days 
(Table: 1, Fig 1). The result found in this study is congruency with data of Turk and Tawaha; they reported that the inhibitoriest effect of allelopathic plants was produced by leaf extracts.

Table 1. Effect of aqueous extracts of two weed species (digera muricata mart. And chinopodium murale 1.$)$ On seed germination of tobacco.

\begin{tabular}{|c|c|c|c|c|c|c|c|}
\hline \multirow{2}{*}{ Period } & \multicolumn{5}{|c|}{ Different concentrations of two weed species } \\
\cline { 2 - 8 } & & \multicolumn{3}{|c|}{ Chenopodium murale L. } & \multicolumn{3}{c|}{ Digera muricata Mart. } \\
\hline & D.W. & $2 \%$ & $4 \%$ & $6 \%$ & $2 \%$ & $4 \%$ & $6 \%$ \\
\hline $2^{\text {nd }}$ days & 20 & 18 & 16 & 14 & 15 & 11 & 7 \\
\hline $4^{\text {th }}$ days & 25 & 21 & 18 & 17 & 18 & 13 & 8 \\
\hline
\end{tabular}

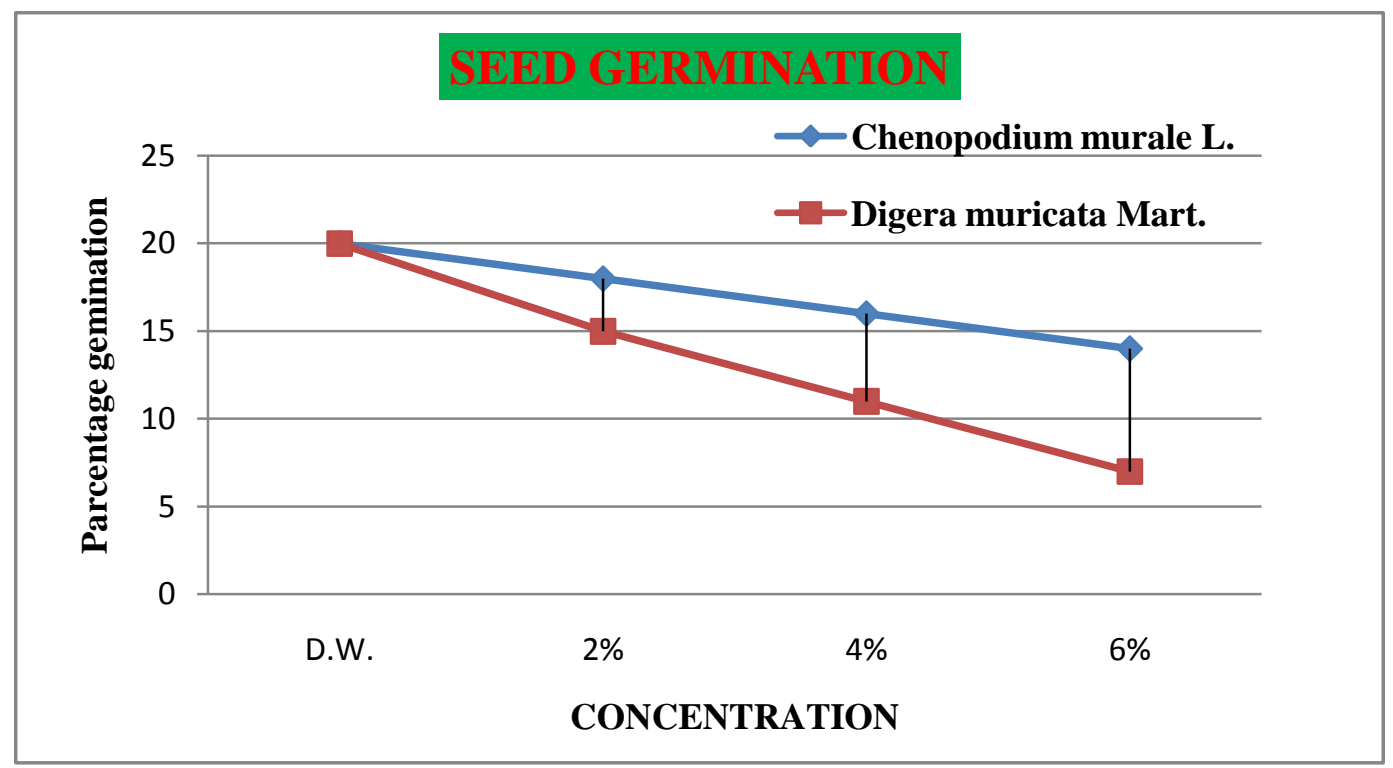

Figure: 1 the percentage of seed germination in different concentration of two weed species on in vitro seed germination of Nicotiana tabacum

Root length: In Nicotiana tabacum $4.28 \mathrm{~cm}$ root length was reported in DDW while various concentrations of inflorescence extracts of Chenopodium murale L. i.e. $2 \%, 4 \%$ and $6 \%$ the root lengths were $2.01 \mathrm{~cm}, 1.98 \mathrm{~cm}$ and $1.21 \mathrm{~cm}$ respectively indicating the reduction of $53.04 \%, 53.73 \%$ and $71.73 \%$ respectively as compared to the control after five days. At the higher concentration (6\%) of leaf extract of Digera muricata Mart. shows most reduction growth on root length (o.34) which indicates the most inhibitory effect (92.06\%) as compared to control after five days.It concludes that when the increasing concentration of weed extracts the root lengths were gradually decreases. Extract of Inflorescence and leaf showed most inhibitory effect, the degree of inhibition increased with the extract concentration (Table-2, Fig 2). Root length was relatively more sensitive to autotoxic allelochemicals than was shoot length. These results are in agreement with earlier studies reporting that water extracts of allelopathic plants were more pronounced effects on radicle growth than on hypocotyl growth or shoot growth interaction (Turk, M.A., M.K. Shantnawi and A.M. Tawaha, 2003; Turk, M.A., and A.M. Tawaha, 2002; Chung M.I. and D.A. Miller, 1995). Such an outcome might be expected, because it is likely that roots are the first to absorb the allelochemicals or autotoxic probability compounds from the environment (Turk, M.A., M.K. Shantnawi and A.M. Tawaha, 2003; Turk, M.A., and A.M. Tawaha, 2002). 
Effects of aqueous extracts of two dominant weed species on seed germination and seedling...

Table: 2 influences of various concentrations of different aqueous extracts made from two weed species (digera muricata mart. And chinopodium murale l.) Plant parts on the root length of 5 days tobacco seedlings.

\begin{tabular}{|c|c|c|c|c|c|c|}
\hline \multirow{2}{*}{ Weed plants } & \multirow{2}{*}{ Concentration } & \multicolumn{4}{|c|}{ Various plant part extracts of two weed species } \\
\cline { 2 - 7 } & & leaf & stem & root & inflorescence & Mean \\
\cline { 2 - 7 } & control/D.W & $4.28 \mathrm{~cm}$ & $4.28 \mathrm{~cm}$ & $4.28 \mathrm{~cm}$ & $4.28 \mathrm{~cm}$ & $4.28 \mathrm{~cm}$ \\
\hline \multirow{3}{*}{$\begin{array}{c}\text { Digera muricata } \\
\text { Mart. }\end{array}$} & $2 \%$ & $1.97 \mathrm{~cm}$ & $2.23 \mathrm{~cm}$ & $2.49 \mathrm{~cm}$ & $1.76 \mathrm{~cm}$ & $2.12 \mathrm{~cm}$ \\
\cline { 2 - 7 } & $4 \%$ & $1.28 \mathrm{~cm}$ & $1.79 \mathrm{~cm}$ & $1.99 \mathrm{~cm}$ & $1.08 \mathrm{~cm}$ & $1.54 \mathrm{~cm}$ \\
\hline \multirow{2}{*}{$\begin{array}{c}\text { Chenopodium } \\
\text { murale L. }\end{array}$} & $6 \%$ & $0.34 \mathrm{~cm}$ & $1.44 \mathrm{~cm}$ & $1.56 \mathrm{~cm}$ & $0.68 \mathrm{~cm}$ & $1.01 \mathrm{~cm}$ \\
\cline { 2 - 7 } & $4 \%$ & $2.38 \mathrm{~cm}$ & $3.01 \mathrm{~cm}$ & $2.89 \mathrm{~cm}$ & $2.01 \mathrm{~cm}$ & $2.57 \mathrm{~cm}$ \\
\hline
\end{tabular}

Shoot length: In Nicotiana tabacum $3.71 \mathrm{~cm}$ shoot length was reported in DW (control medium), while various concentration of inflorescence extracts of two weed species (Digera muricata Mart. and Chinopodium murale L.) i.e. $2 \%, 4 \%$ and $6 \%$ the shoot lengths were decreases as compared to control, after 5 days respectively. The effect of inflorescence extracts was statistically similar to those of leaf extracts at $10 \%$, $25 \%$ and $25 \%$ concentrations. Inflorescence $(0.08 \mathrm{~cm})$ and leaf $(0.19 \mathrm{~cm})$ extracts caused the greatest reduction in shoot length $(97.84 \%)$ and $(94.88 \%)$, respectively at $6 \%$ concentration of Digera muricata Mart. when compared with other part extracts.(Table 3, Fig 3) These findings are supported by Chung and Miller (1995).

Table: 3 Influence of various concentrations of different aqueous extracts made from two weed species (Digera muricata Mart. and Chinopodium murale L.) plant parts on the shoot length of 5 days tobacco seedlings.

\begin{tabular}{|c|c|c|c|c|c|c|}
\hline \multirow{3}{*}{ Weed plants } & \multirow{2}{*}{ Concentration } & \multicolumn{5}{|c|}{ Various plant part extracts of two weed species } \\
\hline & & leaf & stem & root & inflorescence & Mean \\
\hline & control/D.W & $3.71 \mathrm{~cm}$ & $3.71 \mathrm{~cm}$ & $3.71 \mathrm{~cm}$ & $3.71 \mathrm{~cm}$ & $3.71 \mathrm{~cm}$ \\
\hline \multirow{3}{*}{$\begin{array}{c}\text { Digera muricata } \\
\text { Mart. }\end{array}$} & $2 \%$ & $0.97 \mathrm{~cm}$ & $1.48 \mathrm{~cm}$ & $1.81 \mathrm{~cm}$ & $0.73 \mathrm{~cm}$ & $1.25 \mathrm{~cm}$ \\
\hline & $4 \%$ & $0.41 \mathrm{~cm}$ & $1.07 \mathrm{~cm}$ & $1.39 \mathrm{~cm}$ & $0.82 \mathrm{~cm}$ & $0.92 \mathrm{~cm}$ \\
\hline & $6 \%$ & $0.19 \mathrm{~cm}$ & $0.92 \mathrm{~cm}$ & $1.11 \mathrm{~cm}$ & $0.08 \mathrm{~cm}$ & $0.58 \mathrm{~cm}$ \\
\hline \multirow{3}{*}{$\begin{array}{l}\text { Chenopodium } \\
\text { murale L. }\end{array}$} & $2 \%$ & $1.63 \mathrm{~cm}$ & $2.01 \mathrm{~cm}$ & $1.97 \mathrm{~cm}$ & $0.87 \mathrm{~cm}$ & $1.62 \mathrm{~cm}$ \\
\hline & $4 \%$ & $1.31 \mathrm{~cm}$ & $1.89 \mathrm{~cm}$ & $1.93 \mathrm{~cm}$ & $0.45 \mathrm{~cm}$ & $1.40 \mathrm{~cm}$ \\
\hline & $6 \%$ & $1.09 \mathrm{~cm}$ & $1.23 \mathrm{~cm}$ & $1.56 \mathrm{~cm}$ & $0.12 \mathrm{~cm}$ & $1.00 \mathrm{~cm}$ \\
\hline
\end{tabular}




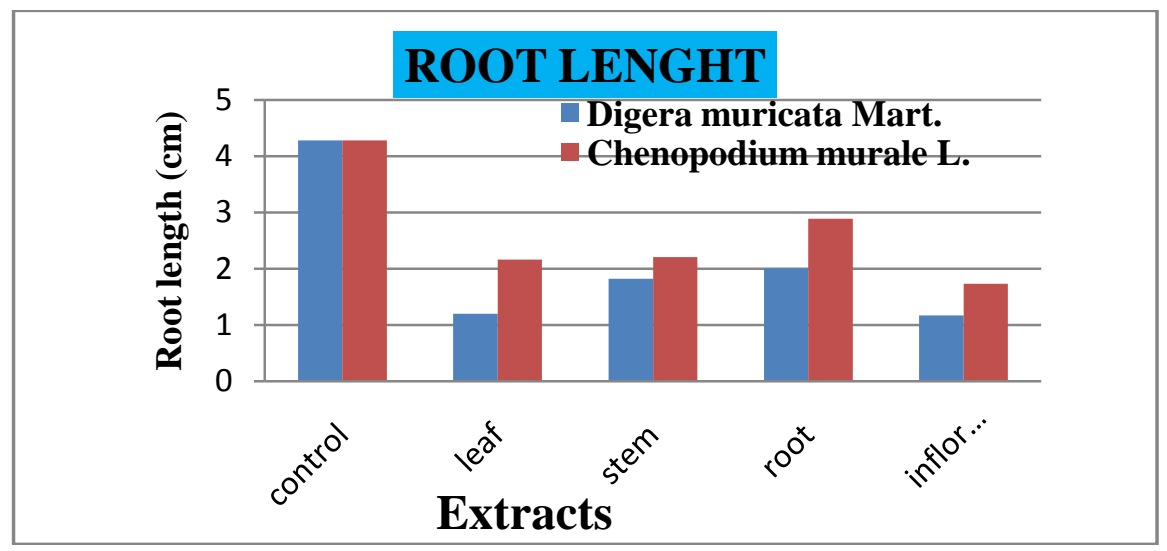

Figure: 1 Influence of different aqueous extracts made from two weed species plant on the root length of Nicotiana tabacum after five days

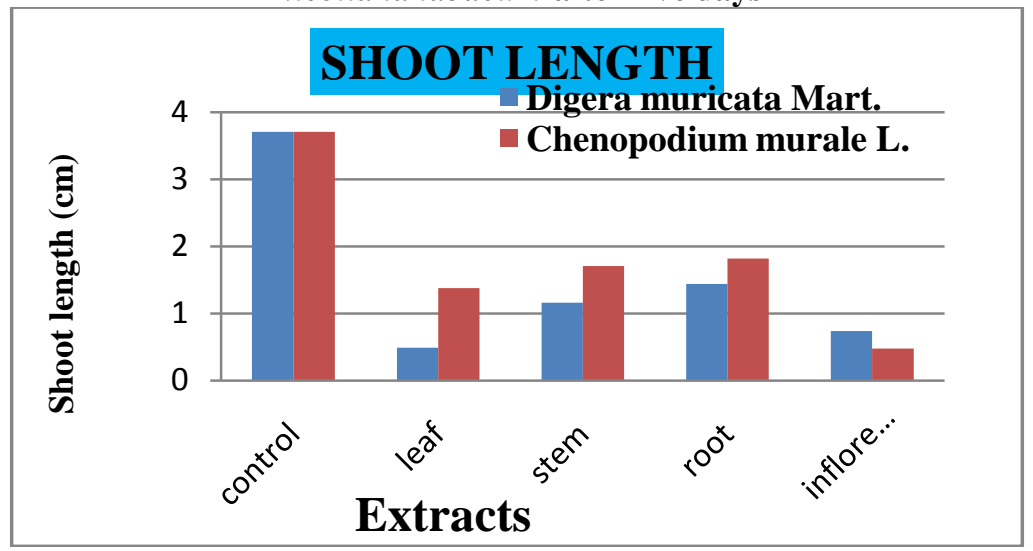

Figure: 1 Influence of different aqueous extracts made from two weed species plant parts on the shoot length of Nicotiana tabacum after five days

\section{CONCLUSION}

After enumeration of the weed species in the crop fields a close association between crop and weed species is find out. At the highest extract concentration, all aqueous extracts significantly reduced seed germination and seedling growth as compared with distilled water. It is difficult to apply our results to a production situation directly, because the concentration of inhibitory substances in aqueous extracts is probably greater than what would be observed under natural conditions.

\section{ACKNOWLEDGEMENT}

The authors express their gratitude to Principal Dr. L. P. Joshi and Trust of Arts, Commerce and Science College, Borsad for necessary facilities and inspiration during the course of investigation.

\section{REFERENCE}

[1]. Chung, I.M. and D.A. Miller, 1995. Natural herbicide potential of alfalfa residues on selected weed species. Agro. J., 87: 920-925.

[2]. Dhavan, S.R. and Narwal, S.S. 1994. Critical assessment of allelopathy bioassays in India. Proc. Int Symp. Allelopathy in Sustainable agriculture, Forestry and environment. New Delhi: Indian society of Allelopathy, IARI.

[3]. Einhellig, F.A., 2002. The Physiology of Allelochemical Action: Clues and Views. In: Allelopathy from Molecules to Ecosystems, Reigosa, M.J. and N. Pedrol (Eds.). Science Publi., Enfield, New Hampshire.

[4]. Narwal SS Tauro P (1994). Allelopathy in Agriculture and Forestry. p. 310. (Scientific publishers, Jodhpur, India).

[5]. Rice, E.L. 1984. Allelopathy. Academic press, orlndo, Florida, USA.

[6]. Turk, M.A. and A.M. Tawaha, 2002. Inhibitory effects of aqueous extracts of black mustard on germination and growth of lentil. Pakistan J. Agron., 1: 28-30.

[7]. Turk, M.K., Shatnawi M.K. and Tawaha A.M., 2003. Inhibitory effects of aqueous extracts of black mustard on germination and growth of alfalfa. Weed Biol. Manag. 3: inpress. 